\title{
A CLINICAL AND SEROLOGICAL STUDY OF RHEUMATOID ARTHRITIS*
}

\author{
BY \\ MARY CORBETT, JUNE M. DOWNES, AND F. R. SCHMID \\ From the Department of Rheumatology and Physical Medicine, Middlesex Hospital, \\ the Rheumatology Research Department, Middlesex Hospital Medical School, London, \\ and the Department of Medicine, Northwestern University, Chicago, Ill.
}

The presence of serological abnormalities in patients with rheumatoid arthritis has been widely reported and their relationship to the course and severity of the disease has been assessed by various workers. Duthie, Brown, Truelove, Baragar, and Lawrie (1964), in a follow-up study of patients 9 years after discharge from hospital, showed that the results of the sheep cell agglutination test (SCAT) had a significant relationship to prognosis. Alexander, Bremner, and Duthie (1960) found that severe disease was most common in patients in whom both the SCAT and the antinuclear factor (ANF) test were positive. Condemi, Barnett, Atwater, Jacox, Mongan, and Vaughan, (1965) also demonstrated a relationship between the presence of ANF and the severity of the disease, though Ward, Johnson, and Holborow, (1964) felt that a positive ANF test did not imply a less favourable prognosis.

Diseases in which autoimmunity is thought to play a part cover a wide range, from the organ-specific such as Hashimoto's thyroiditis, wherein only one tissue is involved, to widespread non-organ-specific conditions such as systemic lupus erythematosus. There is considerable clinical and serological overlap in the autoimmune diseases. In the present investigation, therefore, we have studied the incidence of numerous clinical features of rheumatoid arthritis and of a wide range of autoantibodies in a group of consecutive hospital out-patients with the disease. These have been compared with the findings in a group of control subjects and an attempt has been made to correlate the serological findings with the clinical state of the patients.

\section{Patients and Methods}

120 consecutive patients with "classical" or "definite" rheumatoid arthritis (American Rheumatism Association, 1959) attending routine clinics at the Department of

\footnotetext{
* Read at a meeting of the Heberden Society on November 18,
}

Rheumatology and Physical Medicine of the Middlesex Hospital were invited to participate in this investigation. One refused, one did not fulfil the diagnostic criteria, and eighteen others were unable to attend for domestic reasons.

The 100 patients studied ( 81 female and 19 male) were all Caucasian, and all lived or worked in the Greater London area.

Each patient was asked to invite two healthy friends of the same sex and approximately the same age to act as control subjects. Only sixteen patients were able to find such volunteers and the number of friends included was 28. The remaining control subjects included twelve volunteers from the staff of a London Department Store and 47 members of the staff of a Regional Blood Transfusion Centre. All control subjects were Caucasian and lived or worked in the Greater London area.

The patients ranged in age from 26 to 80 years (mean $57 \cdot 9$, S.D. $11 \cdot 5$ ), the mean being $60 \cdot 6$ for males and $57 \cdot 3$ for females.

The 87 control subjects ranged in age from 19 to 80 years (mean $51 \cdot 3$, S.D. $11 \cdot 3$ ). The difference of $6 \cdot 6$ years in the mean ages of the two groups is statistically significant.

32 of the patients had suffered from rheumatoid arthritis for less than 5 years, 32 for 5 to 9 years, and 36 for 10 years or more. The mean age at onset was $47 \cdot 1$ years for females and $52 \cdot 1$ for males $(47 \cdot 9$ for both sexes together).

The patients and control subjects all underwent detailed clinical examination by the same observer (M.C.) particular attention being paid to joint abnormalities and to systemic manifestations of connective tissue disease.

The haemoglobin (Hb), white blood cell count (WBC), and Westergren erythrocyte sedimentation rate (ESR) were estimated, and the blood was examined for the lupus erythematosus cell phenomenon in all subjects by routine methods. The total plasma protein was measured and paper electrophoresis and quantitative scanning performed.

The Latex FII test and SCAT were performed on each serum using standard techniques. The SCAT was considered positive at a titre of $1: 32$ or greater. Immunofluorescent methods were used to examine the sera for 
the presence of autoantibodies to thyroid, stomach, skeletal, and cardiac muscle, and for antinuclear factors using human thyroid as substrate. Rabbit anti-human $\gamma$-globulin, conjugated with fluorescein isothiocyanate and absorbed with pig-liver powder, was used for these tests.

Complement-fixation tests were performed on those sera which had been shown to contain thyroid or gastric autoantibodies. All sera were tested by the tanned red cell (TRC) haemagglutination test for thyroglobulin antibodies. Those which were weakly positive $(1: 5,1: 10)$ were repeated with thyroglobulin inhibition to confirm the specificity of the result (Gell and Coombs, 1963).

\section{Results}

The clinical condition of the patients and their medication at the time of the investigation are shown in Table I; 81 patients had classical and 19 definite rheumatoid arthritis, 72 being in functional grade 2 . The drug treatment of male and female patients did not differ significantly. None of the control subjects showed clinical evidence of rheumatoid arthritis. The clinical and laboratory findings in patients and control subjects are summarized in Table II and Table III (opposite).

Table IV (overleaf) shows the serological overlap in this group. These results are considered below in detail.
TABLE I

DETAILS OF 100 PATIENTS WITH RHEUMATOID ARTHRITIS

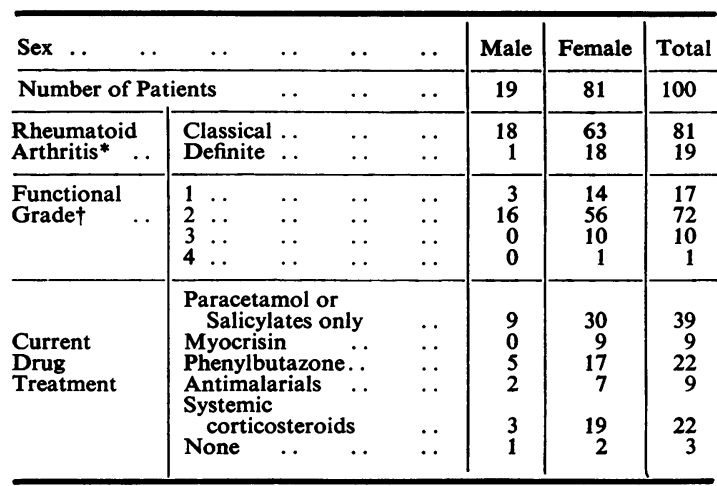

*ARA Diagnostic Criteria (1959).

†Duthie, Thompson, Weir, and Fletcher (1955)

\section{Nodules and Rheumatoid Factor}

The Latex FII test was positive in 78 patients and in five control subjects. The SCAT was positive at titres of $1: 32$ to $1: 1280$ in 43 patients and in one control subject who had a titre of $1: 128$. Both the Latex test and the SCAT were positive in forty patients and in one control.

Rheumatoid nodules were found in 35 patients. 33 (94 per cent.) of the patients with nodules (10 men, 23 women) had positive Latex FII tests

TABLE II

SUMMARY OF CLINICAL FINDINGS IN PATIENTS AND CONTROLS

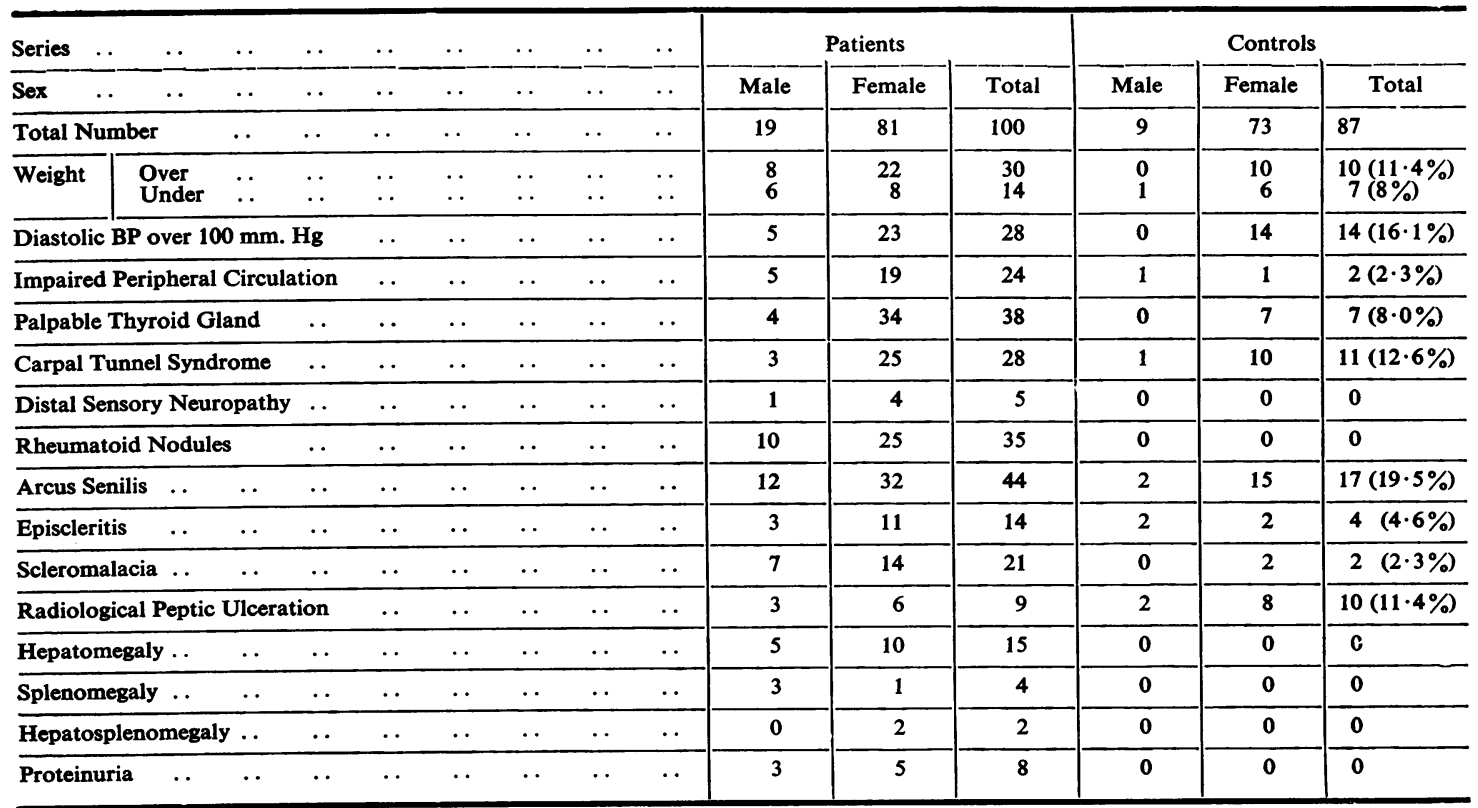


TABLE III

INCIDENCE OF CLINICAL AND SEROLOGICAL ABNORMALITIES IN 100 PATIENTS WITH RHEUMATOID ARTHRITIS AND 87 CONTROL SUBJECTS

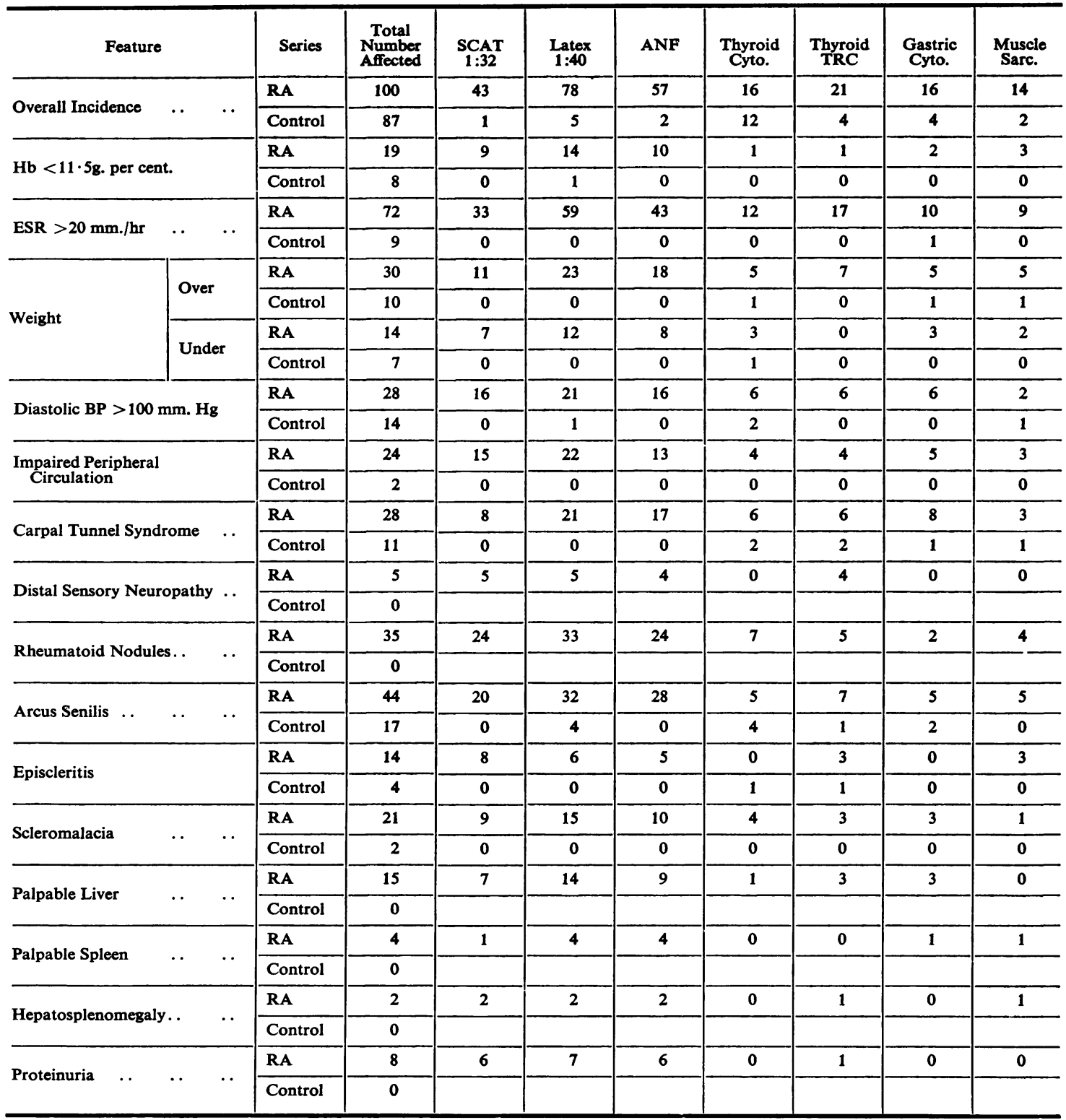

$(P=<0.01)$ : of these, nine men and sixteen women had a positive SCAT (71 per cent.) $(\mathbf{P}=$ $<0.01)$. Two patients with nodules had a positive SCAT but a negative Latex test.

Of the 65 patients without nodules, 45 (69 per cent.) had a positive Latex FII test and 16 (25 per cent.) a positive SCAT.

\section{Antinuclear Factor}

Antinuclear factor of the diffuse type was present in 57 patients, in only one of whom were L.E.-cells demonstrated in the peripheral blood. ANF was found in two control subjects. ANF was present in all six patients with splenomegaly, though none had ever had a recorded leucopenia. 28 of the 43 
TABle IV

SEROLOGICAL OVERLAP IN 100 PATIENTS WITH RHEUMATOID ARTHRITIS AND 87 CONTROL SUBJECTS

\begin{tabular}{|c|c|c|c|c|c|c|c|c|c|c|c|}
\hline Feature & & & Series & $\begin{array}{c}\text { Total } \\
\text { Number }\end{array}$ & $\begin{array}{c}\text { SCAT } \\
>1: 32\end{array}$ & $\begin{array}{l}\text { Latex } \\
>1: 40\end{array}$ & ANF & $\begin{array}{c}\text { Thyroid } \\
\text { Cyto. }\end{array}$ & $\begin{array}{c}\text { Thyroid } \\
\text { TRC }\end{array}$ & $\begin{array}{c}\text { Gastric } \\
\text { Cyto. }\end{array}$ & $\begin{array}{c}\text { Muscle } \\
\text { Sarc. }\end{array}$ \\
\hline \multirow{2}{*}{ SCAT $>1: 32}$. & \multirow{2}{*}{$\cdots$} & \multirow{2}{*}{$\cdots$} & $\mathbf{R A}$ & 43 & & 41 & 25 & 8 & 9 & 4 & 5 \\
\hline & & & Control & 1 & & 1 & 0 & 0 & 0 & 0 & 0 \\
\hline \multirow{2}{*}{ Latex Test $>1: 40$} & \multirow{2}{*}{$\cdots$} & \multirow{2}{*}{$\cdots$} & RA & 78 & 41 & & 50 & 14 & 13 & 15 & 12 \\
\hline & & & Control & 5 & 1 & & 0 & 0 & 0 & 0 & 0 \\
\hline \multirow{2}{*}{ ANF } & \multirow{2}{*}{$\cdots$} & \multirow{2}{*}{$\cdots$} & $\mathbf{R A}$ & 57 & 25 & 50 & & 2 & 8 & 8 & 5 \\
\hline & & & Control & 1 & 0 & 0 & & 0 & 0 & 0 & 0 \\
\hline \multirow{2}{*}{ Thyroid Antibodies } & \multirow{2}{*}{$\cdots$} & \multirow{2}{*}{$\cdots$} & $\mathbf{R A}$ & 31 & 14 & 22 & 9 & 16 & 21 & 8 & 6 \\
\hline & & & Control & 16 & 0 & 0 & 0 & 12 & 4 & 1 & 1 \\
\hline \multirow{2}{*}{ Gastric Antibodies } & \multirow{2}{*}{. } & \multirow{2}{*}{$\cdots$} & RA & 16 & 4 & 15 & 8 & 6 & 4 & & 6 \\
\hline & & & Control & 4 & 0 & 0 & 0 & 1 & 0 & & 0 \\
\hline \multirow{2}{*}{ Muscle Sarc. } & \multirow{2}{*}{. } & \multirow{2}{*}{$\cdots$} & $\mathbf{R A}$ & 14 & 5 & 12 & 5 & 4 & 3 & 6 & \\
\hline & & & Control & 2 & 0 & 0 & 0 & 1 & 1 & 0 & \\
\hline
\end{tabular}

patients (65 per cent.) with positive SCAT had ANF, while ANF was present in 29 of the 57 patients (51 per cent.) with negative SCAT $(P=0 \cdot 1-0 \cdot 2)$. ANF was found in fifty of the 78 patients (64 per cent.) with positive Latex FII tests and in seven of the 22 ( 32 per cent.) in whom this test was negative $(P=0.01-0.02)$. The presence of ANF was unrelated to the severity of the disease.

\section{Erythrocyte Sedimentation Rate}

The ESR was greater than $20 \mathrm{~mm}$./hr in 72 patients and in nine control subjects. One control had a sore throat at the time of examination, but no explanation of the raised ESR could be found in the others. Neither the SCAT which was positive in 33 of the 72 patients with a raised ESR $(P=0 \cdot 3-0 \cdot 5)$, nor ANF which was present in 43 patients with a raised ESR $(P=0 \cdot 3-0 \cdot 5)$ was significantly related to the level of the ESR.

\section{Anaemia and Gastric Antibodies}

The haemoglobin was less than $11.5 \mathrm{~g} . / 100 \mathrm{ml}$. in nineteen patients ( 2 men and 17 women) and in eight control subjects, all of whom were premenopausal women. The anaemias were hypochromic or normochromic: no macrocytosis was demonstrated. Eighteen of the anaemic patients were being treated with salicylates and four with systemic steroids. Rheumatoid factor was demonstrated in fifteen of the anaemic patients ( 79 per cent.) and ANF was present in ten (53 per cent.). These figures do not differ significantly from those found for the entire group (rheumatoid factor 18 per cent., ANF 57 per cent.).
Antibodies to gastric parietal cells were demonstrated in seventeen of the 100 patients and in four controls $(P=0.01-0.02)$. There was no relationship between the presence of gastric antibodies and iron-deficiency anaemia. The four control subjects (all female) with gastric antibodies in their sera were not anaemic.

\section{Clinical and Serological Thyroid Abnormalities}

Thyroid antibodies were present in 31 patients and sixteen controls $(P=0.05-0 \cdot 1)$. Cytoplasmic antibodies were demonstrated in sixteen patients and twelve controls and the TRC test for thyroglobulin antibodies was positive in 21 patients and four controls $(P=<0 \cdot 01)$. No patients were thyrotoxic: two gave a clinical impression of hypothyroidism which was not confirmed by radio-iodine studies. All the control subjects were euthyroid.

\section{Muscle Antibodies}

Sarcolemmal staining of skeletal muscle was shown by immunofluorescent methods in fourteen patients and two controls $(P=0 \cdot 01-0.05)$. Striational staining was not observed. There was no clinical evidence of muscle disease in either patients or controls.

\section{Sex Incidence of Autoantibodies}

The non-organ-specific autoantibodies (ANF, SCAT, Latex FII) were all present in a higher proportion of male than female patients:

ANF: male 78 per cent., female 54 per cent. SCAT: male 53 per cent., female 41 per cent. Latex FII: male 84 per cent., female 78 per cent. 
For organ-specific antibodies, the position was reversed:

Thyroid: male 22 per cent., female 35 per cent.

Stomach: male 9 per cent., female 18 per cent.

Muscle: male 5 per cent., female 16 per cent.

There was a similar tendency in the control group, though the number of males studied was too small for statistical evaluation.

\section{Weight}

44 per cent. of the patients and 20 per cent. of the controls were outside the range of "desirable" weights given by the Metropolitan Life Insurance Company of New York (1959). The patients tended to become thinner with increasing duration of disease, but there was no relationship between body weight and the severity of the disease. Rheumatoid factor was demonstrated in 23 (77 per cent.) of the overweight patients and thirteen ( 93 per cent.) of those who were underweight. The incidence of ANF was similar in the two groups (overweight, 60 per cent.: underweight, 57 per cent.).

\section{Median Nerve Compression}

The criteria used for the diagnosis of median nerve compression were:

(1) A history of nocturnal paraesthesiae in the hand:

(2) Poor two-point discrimination in the territory of the median nerve:

(3) Either a positive Tinel sign or a positive compression test.

Most patients had responded to local steroid injection which has been recommended by Crisp (1959) and others as a diagnostic test. Routine electromyography was not performed. This syndrome was found more often in patients $(28$ per cent.) than in controls (13 per cent.) $(P=<0.01)$ and in more female patients ( 31 per cent.) than male patients (16 per cent.). The sex incidence in the control subjects was equal. Rheumatoid factor was demonstrated in 21 ( 75 per cent.) of the patients with median nerve compression and ANF was present in seventeen (61 per cent.) of them. These incidences are similar to those found for the group as a whole.

\section{Discussion}

The difficulties in comparing both clinical and serological findings in different samples of patients with rheumatoid arthritis are notorious. The clinical assessment has been much simplified by the general acceptance of the American Rheumatism Association's diagnostic criteria, but even when these are observed the method of selection of patients can influence the results of a study. Widely differing findings are reported from samples taken from hospital in-patients, out-patients, and from population surveys. For example, Kellgren and Ball (1959) demonstrated rheumatoid factor in 51 per cent. of hospital out-patients and 87 per cent. of in-patients, while Feltkamp (1966) found rheumatoid factor in 36 per cent. of individuals in a population survey and in 62.5 per cent. of patients selected as known cases of rheumatoid arthritis. Feltkamp also found a significant relationship between the presence of rheumatoid factor and of ANF in the population study sample, but not in the "selected" patients. However, serological findings, particularly the incidence of ANF, can vary considerably with technique (Hijmans, Schuit, Mandema, Nienhuis, Feltkamp, Holborow, and Johnson, 1964), further complicating comparisons between different workers' results. It seems important, therefore, that the source of clinical material and technical methods should be described in detail.

In this study the presence of rheumatoid factor as demonstrated by both the SCAT and the Latex test was found to be significantly associated with nodules, in agreement with the findings of Kellgren and Ball (1959). The presence of rheumatoid factor was not related to the severity or duration of the disease or to any other individual clinical feature.

The association between ANF and rheumatoid factor as measured by the SCAT did not reach a significant level in this series, though a significant relationship between ANF and positive Latex FII tests was observed. This difference may arise because the Latex FII test is less specific than the SCAT. We did not find the presence of rheumatoid factor and ANF together to be associated with more severe disease, as reported by Alexander and others (1960). The presence or absence of ANF was not related to the duration or severity of the disease or to any other individual feature in this study.

Our investigation of abnormalities associated with organ-specific autoimmune diseases revealed less significant differences between patients and control subjects that was shown with the non-organ-specific antibodies.

Mackay and Perry (1960), Hijmans, Doniach, Roitt, and Holborow (1961), and Feltkamp (1966) all found the incidence of thyroid antibodies in patients with rheumatoid arthritis to be no greater than in control subjects. In the present study, the 
incidence of thyroid cytoplasmic antibodies was similar in patients and controls, though the TRC haemagglutination test for thyroglobulin antibodies was positive in 21 per cent. of patients and only 4 per cent. of controls $(P=<0.01)$. This difference may be partly due to the age difference between the two groups, though data taken from a large number of normal subjects suggests that the increase in incidence to be expected between 51 and 58 years would be only about 2 per cent. (Doniach and Roitt, 1967).

We found both gastric and muscle antibodies in more patients than control subjects; no related clinical abnormalities were observed.

The overall results of the serological tests (Table IV) show considerable overlap between the nonorgan-specific autoantibodies (SCAT, Latex, ANF), with a lower incidence and less overlap in the organ-specific autoantibodies.

The high incidence of autoantibodies in the patients with rheumatoid arthritis, compared with controls, indicates that an abnormality of the immune mechanism is present in this disease, though the part which it plays is not yet clear.

The present study confirms the relationship between the presence of rheumatoid factor and nodules, but has failed to reveal any other associations between clinical and serological findings in rheumatoid arthritis. The heterogeneity of our group of patients, selected at random and varying widely in the duration and severity of their disease, may make it difficult to recognize such relationships. It is planned, therefore, to repeat the study on newlydiagnosed rheumatoid arthritics and to look for clinico-pathological associations in this more homogeneous group.

\section{Summary}

Clinical and serological findings in 100 patients with "classical" or "definite" rheumatoid arthritis were compared with those in 87 healthy control subjects.

The incidence of non-organ-specific autoantibodies
(SCAT, ANF) was much higher in patients than in controls, while the incidence of organ-specific autoantibodies (thyroid, stomach, and muscle) was slightly greater.

The presence of rheumatoid factor was significantly associated with nodules. There was no significant relationship between the results of serological tests and the duration or severity of the disease or with any other clinical findings, although interpretation is complicated by the clinical heterogeneity of the group.

We wish to thank Dr. A. C. Boyle, Dr. S. Mattingly, and Dr. O. Savage for their kind advice and encouragement and for permission to study their patients, and Dr. I. M. Roitt for his valuable help in the preparation of this paper. The Clinical Research Committee kindly provided facilities in the Institute of Clinical Research. Valuable technical assistance was given by the staff of the Rheumatology Research Department of the Middlesex Hospital Medical School. Biochemical and haematological tests were carried out by the Courtauld and Bland Sutton Institutes.

We are grateful to Dr. E. Lewis-Faning, who advised us on the design of this study, to the London Department Store which allowed us to examine their staff, to the Director and Staff of the North London Blood Transfusion Centre, Edgware, for facilities to examine their staff, and to the control subjects themselves.

One of us (J.M.D.) is in receipt of a grant from the Muscular Dystrophy Group of Great Britain.

\section{DISCUSSION}

Dr. E. J. Holborow (Taplow): Did you find any association between any of these autoantibodies in particular patients?

DR. CORBETT: There was no particular association, except in a very few cases. A fairly large number had one or more, obviously, but there was no definite pattern.

DR. D. J. WARD (Oswestry): Did any of the patients have Sjögren's syndrome?

DR. CORBETT: Yes, two, but they also fitted the criteria for classical rheumatoid arthritis before a diagnosis of Sjögren's syndrome was made. We found that one of them had speckled antinuclear antibodies but the other had nothing of that sort.

\section{REFERENCES}

Alexander, W. R. M., Bremner, J. M., and Duthie, J. J. R. (1960). Ann. rheum. Dis., 19, 338 (Incidence of the antinuclear factor in human sera).

American Rheumatism Association (1959). Ibid., 18, 49 (Diagnostic criteria for rheumatoid arthritis: 1958 revision).

Condemi, J. J., Barnett, E. V., Atwater, E. C., Jacox, R. F., Mongan, E. S., and Vaughan, J. H. (1965). Arthr. and Rheum., 8, 1080 (The significance of antinuclear factors in rheumatoid arthritis).

Crisp, E. J. (1959). Brit. med. J., 2, 22 (Acroparaesthesia and the carpal tunnel).

Doniach, D., and Roitt, I. M. (1967). In press. 
Duthie, J. J. R., Brown, P. E., Truelove, L. H., Baragar, F. D., and Lawrie, A. J. (1964). Ann. rheum. Dis., 23, 193 (Course and prognosis in rheumatoid arthritis: a further report).

—, Thompson, M., Weir, M. M., and Fletcher, W. Bell (1955). Ibid., 14, 133 (Medical and social aspects of the treatment of rheumatoid arthritis with special reference to factors affecting prognosis).

Feltkamp, T. E. W. (1966). Thesis. University of Amsterdam. "Idiopathic Autoimmune Diseases. A Study of Their Serological Relationship."

Gell, P. G. H., and Coombs, R. R. A. (1963). "Clinical Aspects of Immunology". Blackwell, Oxford.

Hijmans, W., Doniach, D., Roitt, I. M., and Holborow, E. J. (1961). Brit. med. J., 2, 909 (Serological overlap between lupus erythematosus, rheumatoid arthritis, and thyroid auto-immune disease).

—- Schuit, H. R. E., Mandema, E., Nienhuis, R. L. F., Feltkamp, T. E. W., Holborow, E. J., and Johnson, G. D. (1964). Ann. rheum. Dis., 23, 73 (Comparative study for the detection of antinuclear factors with the fluorescent antibody technique).

Kellgren, J. H., and Ball, J. (1959). Brit. med. J., 1, 523 (Clinical significance of the rheumatoid serum factor).

Mackay, I. R., and Perry, B. T. (1960). Aust. Ann. Med., 9, 84 (Autoimmunity in human thyroid disease).

Metropolitan Life Insurance Company of New York (1959). Statist. Bull., 40, 1 (New weight standards for men and women).

Ward, D. J., Johnson, G. D., and Holborow, E. J. (1964). Ann. rheum. Dis., 23, 306 (Antinuclear factor in rheumatoid arthritis).

Une étude clinique et sérologique de l'arthrite rhumatismale

\section{RÉSUMÉ}

On compara les éléments cliniques et sérologiques chez 100 malades ayant une arthrite rhumatismale "classique" ou "définie" avec ceux de 87 sujets normaux.

La fréquence d'autoanticorps non spécifiques d'un organe (Waaler-Rose, facteur antinucléaire) fut beaucoup plus élevée chez les malades que chez les témoins, tandis que celle des autoanticorps spécifiques d'un organe (thyroïde, estomac et muscle) fut légèrement plus faible.

L'existence du facteur rhumatoïde fut associée d'une façon significative avec des nodules. Il n'y eut pas de rapport significatif entre les résultats des réactions sérologiques et la durée ou la gravité de la maladie, ou tout autre élément clinique, bien que l'interprétation soit compliquée par l'hétérogénéité clinique du groupe.

\section{Estudio clínico y serológico de la artritis reumatoide}

\section{SUMARIO}

Se compararon los resultados clínicos y serológicos en 100 enfermos con artritis reumatoide "clásica" o "definida" con los en 87 sujetos normales.

La frecuencia de autoanticuerpos non específicos de órgano (Waaler-Rose, factor antinuclear) fué mucho más elevada en los enfermos que en los testigos, mientras la de autoanticuerpos específicos de órgano (tiroide, estómago y músculo) fué sólo un poco elevada.

La existencia del factor reumatoide fué asociada de una manera significativa con nódulos. No hubo relación significativa entre los resultados de las reacciones serológicas y la duración o la gravedad de la enfermedad o cualquier otro elemento clínico, no obstante la dificultad de interpretación debida a la heterogeneidad clínica del grupo. 